\title{
Paenibacillus strains with nitrogen fixation and multiple beneficial properties for promoting plant growth
}

\author{
Xiaomeng Liu ${ }^{1}$, Qin $\mathbf{L i}^{1}{ }^{1}$, Yongbin $\mathrm{Li}^{1}{ }^{1}$, Guohua Guan ${ }^{1}$, Sanfeng Chen ${ }^{\text {Corresp. } 1}$ \\ ${ }^{1}$ State Key Laboratory for Agrobiotechnology and College of Biological Sciences, China Agricultural University, China, Beijing \\ Corresponding Author: Sanfeng Chen \\ Email address: chensf@cau.edu.cn
}

Paenibacillus is a large genus of Gram-positive, facultative anaerobic, endospore-forming bacteria. The genus Paenibacillus currently comprises more than 150 named species, approximately 20 of which have nitrogen-fixation ability. The $\mathrm{N}_{2}$-fixing Paenibacillus strains have potential uses as a bacterial fertilizer in agriculture. In this study, 179 bacterial strains were isolated by using nitrogen-free medium after heating at $85^{\circ} \mathrm{C}$ for $10 \mathrm{~min}$ from 69 soil samples collected from different plant rhizospheres in different areas. Of the 179 bacterial strains, 25 Paenibacillus strains had nifH gene encoding Fe protein of nitrogenase and showed nitrogenase activities. Of the $25 \mathrm{~N}_{2}$-fixing Paenibacillus strains, 22 strains produced indole-3-acetic acid (IAA). 21 strains out of the $25 \mathrm{~N}_{2}$-fixing Paenibacillus strains inhibited at least one of the 6 plant pathogens Rhizoctonia cerealis, Fusarium graminearum, Gibberella zeae, Fusarium solani, Colletotrichum gossypii and Alternaria longipes. 18 strains inhibited 5 plant pathogens and Paenibacillus sp. SZ-13b could inhibit the growth of all of the 6 plant pathogens. According to the nitrogenase activities, antibacterial capacities and IAA production, we chose 8 strains to inoculate wheat, cucumber and tomato. Our results showed that the 5 strains Paenibacillus sp. JS-4, Paenibacillus sp. SZ-10, Paenibacillus sp. SZ-14, Paenibacillus sp. BJ-4 and Paenibacillus sp. SZ-15 significantly promoted plant growth and enhanced the dry weight of plants. Hence, the five strains have the greater potential to be used as good candidates for biofertilizer to facilitate sustainable development of agriculture. 
1

2

3

4

5 State Key Laboratory for Agrobiotechnology and College of Biological Sciences, China

6 Agricultural University, Beijing, 100193, P. R. China

7 * Correspondence: Sanfeng Chen

8

9

10

11

12

13

14

15

16

17

18

19

20

21

\section{Paenibacillus strains with nitrogen fixation and multiple beneficial properties for promoting plant growth}

\author{
Xiaomeng Liu, Qin Li, Yongbin Li, Guohua Guan, Sanfeng Chen*
}

E-mail: chensf@cau.edu.cn

Tel.: +86-10-62731551

10

1

12

13

15 
23 Abstract

Paenibacillus is a large genus of Gram-positive, facultative anaerobic, endospore-forming bacteria. The genus Paenibacillus currently comprises more than 150 named species, approximately 20 of which have nitrogen-fixation ability. The $\mathrm{N}_{2}$-fixing Paenibacillus strains have potential uses as a bacterial fertilizer in agriculture. In this study, 179 bacterial strains were isolated by using nitrogen-free medium after heating at $85^{\circ} \mathrm{C}$ for $10 \mathrm{~min}$ from 69 soil samples collected from different plant rhizospheres in different areas. Of the 179 bacterial strains, 25 Paenibacillus strains had nifH gene encoding Fe protein of nitrogenase and showed nitrogenase activities. Of the $25 \mathrm{~N}_{2}$-fixing Paenibacillus strains, 22 strains produced indole-3-acetic acid (IAA). 21 strains out of the $25 \mathrm{~N}_{2}$-fixing Paenibacillus strains inhibited at least one of the 6 plant pathogens Rhizoctonia cerealis, Fusarium graminearum, Gibberella zeae, Fusarium solani, Colletotrichum gossypii and Alternaria longipes. 18 strains inhibited 5 plant pathogens and

Paenibacillus sp. SZ-13b could inhibit the growth of all of the 6 plant pathogens. According to the nitrogenase activities, antibacterial capacities and IAA production, we chose 8 strains to inoculate wheat, cucumber and tomato. Our results showed that the 5 strains Paenibacillus sp. sustainable development of agriculture. 


\section{Introduction}

46 Nitrogen is an essential element to affect the yields of crops by influencing leaf area

47 development and photosynthetic efficiency (Fang et al. 2018). The application of chemical nitrogen fertilizer can improve soil fertility and thus agricultural production. High rates of nitrogen fertilizer might boost yields, but can reduce the quality of agricultural products. However, approximately $100 \mathrm{Tg}$ chemical nitrogen is applied in agricultural products every year, while only $17 \mathrm{Tg}$ nitrogen is accounted for in crops (Erisman et al. 2008). Excessive use of chemical fertilizer has resulted in seriously negative impacts, such as soil hardening and acidification, increased greenhouse gas $\left(\mathrm{N}_{2} \mathrm{O}\right)$ emissions and enhanced nitrogen deposition (Jiao et al. 2018; Reay et al. 2012).

The Paenibacillus genus was first reclassified as a separate genus on the basis of the $16 \mathrm{~S}$ rRNA gene sequences by Ash et al. (Ash et al. 1993). Since its creation, the Paenibacillus genus embody more than 100 validly named species. Approximately 20 members of the Paenibacillus genus had been reported to have the capacity of fixing nitrogen, such as: Paenibacillus polymyxa,

Paenibacillus macerans, Paenibacillus azotofixans, Paenibacillus sabinae, Paenibacillus sonchi, Paenibacillus forsythia, Paenibacillus sophorae, Paenibacillus taohuashanense and Paenibacillus beijingensis (Grau \& Wilson 1962; Hong et al. 2009; Jin et al. 2011; Ma et al. 2007; Ma \& Chen 2008; Seldin et al. 1984; Wang et al. 2014; Witz et al. 1967; Xie et al. 2012). Paenibacillus is a group of Gram-positive, aerobic or facultative anaerobic, rod-shaped, endospore-forming bacteria. The widely distributed Paenibacillus bacteria could tolerate extreme environments and interact 
with a variety of plants (Navarronoya et al. 2012). Currently, some Paenibacillus strains play a great role in agriculture and industry (Seldin 2011).

Plant rhizosphere is a habitat of functional microorganisms, which encompasses a complex and dynamic zone of interactions between networks of organisms and their plant hosts (Garcia \& Kao-Kniffin 2018; Zhalnina et al. 2018). A large amount of strains isolated from plant rhizospheres are able to directly or indirectly promote plant growth, development and evolution, which are termed as plant growth-promoting rhizobacteria (PGPR) (Mohamed et al. 2019). PGPR can stimulate plant growth by a diversity of mechanisms including fixing nitrogen from atmosphere, solubilizing phosphorus, synthesizing siderophore, producing antimicrobial substances (antibiotics, bacteriocins and small peptides) and plant hormones such as indole, cytokinins or gibberellins (Graham et al. 2000; Neilands 1993). Given these advantages, PGPR are widely used in sustainable agriculture to promote plant growth and control fungal pathogens (Verma et al. 2018). Some of Paenibacillus species can influence plant growth by one or more of mechanisms mentioned above (Li et al. 2017; Weselowski et al. 2016; Xie et al. 2016). Nowadays, with the rapid growth of population, most regions have increased the cereals production by the overuse of fertilizers, which not only accounts for a larger percentage of farmers' expenses but also increase risks of negative effect on environment (Curatti \& Rubio 2014; Ivleva et al. 2016; Tayefeh et al. 2018). It is the best choice to select the environmentally friendly Paenibacillus strains to substitute for chemical fertilizer due to its broad host range and its ability to secrete plant growth-enhancing substances and produce different kinds of antimicrobial substances (Cho et al. 2007; Da Mota \& Seldin 2008; Fortes et al. 2008; Li et al. 2007; Timmusk et al. 2009).

The Paenibacillus strains have the potential to increase agricultural productivity, including weight of crops and root growth. The main purpose of this research was to isolate and identify 
Paenibacillus strains, to study the effect of these isolates on plant growth, and then to select the potential bacterial strains to be used in sustainable development of agricultural production.

\section{Materials \& Methods}

\section{Sample collection, isolation procedures and culture conditions}

Sixty-nine soil samples were collected from various plant rhizospheres in different areas of China, which were described in Table 1 in detail. The soil samples were diluted gradiently by $0.9 \%$ saline solution (up to $10^{-5}$ ) and then screened on nitrogen-free medium after heating at $85^{\circ} \mathrm{C}$ for 10 min. Three replicates per dilution were made. The nitrogen-free medium contained $20 \mathrm{~g}$ sucrose, $0.1 \mathrm{~g} \mathrm{~K}_{2} \mathrm{HPO}_{4}, 0.4 \mathrm{~g} \mathrm{KH}_{2} \mathrm{PO}_{4}, 0.2 \mathrm{~g} \mathrm{MgSO}_{4} \cdot 7 \mathrm{H}_{2} \mathrm{O}, 0.01 \mathrm{~g} \mathrm{NaCl}, 0.01 \mathrm{~g} \mathrm{FeCl}_{3}, 0.002 \mathrm{~g} \mathrm{Na}_{2} \mathrm{MoO}_{4}$ and 1.2-1.4 g agar per litre of water. Single colony for each possible species was selected after cultivation for $3-5$ days at $30^{\circ} \mathrm{C}$. To reduce the influence of nitrogen from the soils and purify the strains, the isolates were transferred to the fresh nitrogen-free medium. The strains isolated in this study and their sources were listed in Table 1. All isolates are stored in our lab, and 16S rRNA sequences are available in database of GenBank.

\section{Amplification, cloning and sequencing of nifH gene}

PCR amplification of nifH gene was carried out using the following primers: forward 5'GGCTGCGATCC(CGA)AAGGCCGATC(CGA)ACCCG-3' and reverse 5'CTG(GCA)GCCTTGTTTCGCGGAT(CG)GGCATGGC-3' as described by Ding et al. (Ding et al. 2005). The nifH gene fragments were purified using TIANgel Midi Purification Kit (Tiangen Biotech Co., LTD. Cat. \#DP210) and ligated to vector pGEM-T (Promega Co., Cat. \#R6881) at 
108

109

110

111

112

113

114

115

116

117

118

119

120

121

122

123

124

125

126

127

128

$16^{\circ} \mathrm{C}$ overnight. Recombinant plasmids were transformed into Escherichia coli JM109 and transformants were selected by blue/white screening procedure. Plasmids containing nifH gene were extracted and purified. Purified plasmids were then sequenced using the M13F and M13R primers by Shanghai Majorbio Bio-pharm Technology Co., LTD.

\section{Morphological characterization of strains}

For observation of colony morphology, the bacterial strains were spread on Luria-Bertani (LB) agar. After incubation at $37^{\circ} \mathrm{C}$ overnight, single colony was observed. Cell morphology was viewed by optical microscopy (Olympus CX22LED, Japan).

\section{Sequence analysis and construction of the phylogenetic trees}

All strains were cultured in LB broth medium overnight. After collection of bacteria by centrifugation, genomic DNA of isolates was extracted and purified using the TIANamp Bacteria DNA Kit (Tiangen Biotech Co., LTD. Cat. \#DP302) according to the manufacturer's instructions. The amplication of $16 \mathrm{~S}$ rRNA genes was performed with the universal primers: 27F (5'AGAGTTTGATC(AC)TGGCTCAG-3') and 1492R (5'-CGG(CT)TACCTTGTTACGACTT-3') as described by Khan et al. (Khan et al. 2014). Then the 16S rRNA gene fragments were ligated into vector pGEM-T (Promega Co., Cat. \#R6881) and sequenced by Shanghai Majorbio Biopharm Technology Co., LTD. The sequences of 16S rRNA gene were submitted to nucleotide database of GenBank and the accession numbers were displayed in Table 1. And the sequences were aligned with BLAST software from NCBI (http://www.ncbi.nlm.nih.gov/Blast/).

The phylogenetic tree was constructed from evolutionary distance matrices using the neighbor-joining method with MEGA6 software package (Tamura et al. 2013). Bootstrap analysis 
129

130

131

132

133

134

135

136

137

138

139

140

141

142

143

144

145

146

147

148

149

was performed with 1000 cycles, and only bootstrap values greater than $50 \%$ were shown at the branch points.

\section{Nitrogenase activity assay}

For determination of the nitrogenase activity, strains were grown in $20 \mathrm{~mL}$ of LB broth medium in $50 \mathrm{~mL}$ flasks shaken at $200 \mathrm{rpm}$ overnight at $37^{\circ} \mathrm{C}$. The cultures were collected by centrifugation, precipitations were washed three times with sterilized water and then resuspended in nitrogen-limited medium (per liter: $26.3 \mathrm{~g} \mathrm{Na}_{2} \mathrm{HPO}_{4} \cdot 12 \mathrm{H}_{2} \mathrm{O}, 3.4 \mathrm{~g} \mathrm{KH}_{2} \mathrm{PO}_{4}, 26 \mathrm{mg} \mathrm{CaCl} \cdot 2 \mathrm{H}_{2} \mathrm{O}$, $30 \mathrm{mg} \mathrm{MgSO}_{4}, 0.3 \mathrm{mg} \mathrm{MnSO}_{4}, 36 \mathrm{mg}$ ferric citrate, $7.6 \mathrm{mg} \mathrm{Na}_{2} \mathrm{MoO}_{4} \cdot 2 \mathrm{H}_{2} \mathrm{O}, 10 \mu \mathrm{g} p$ aminobenzoic acid, $10 \mu \mathrm{g}$ biotin, $0.4 \%(\mathrm{w} / \mathrm{v})$ glucose and $0.03 \%(\mathrm{w} / \mathrm{v})$ glutamic acid). The nitrogenase activity was determined using the acetylene reduction assay and expressed as nmol $\mathrm{C}_{2} \mathrm{H}_{4} \cdot \mathrm{mg}^{-1}$ protein $\cdot \mathrm{h}^{-1}($ Wang et al. 2013; Wang et al. 2018).

\section{Assessment of antagonistic activity against plant pathogens}

The assessment of the Paenibacillus strains isolated from the rhizospheres for antagonism against 6 plant pathogens including Rhizoctonia cerealis (ACCC 37393), Fusarium graminearum (ACCC 36249), Gibberella zeae (CGMCC 3.2873), Fusarium solani (CGMCC 3.17848), Colletotrichum gossypii (CGMCC 3.1859) and Alternaria longipes (CGMCC 3.2875), was performed in agar plate assay using potato dextrose agar (PDA). The fungal pathogens were inoculated in the center of the agar plate, and the Paenibacillus strains were placed at a distance of $3.5 \mathrm{~cm}$ from the center of the plate. After 3-7 days of incubation at $30^{\circ} \mathrm{C}$, the plates were examined and measured for fungal pathogens growth inhibited zones around the Paenibacillus strains. All tests were carried out in three duplicates. 
150

151

152

153

154

155

156

157

158

159

160

161

162

163

164

165

166

167

168

169

170

\section{Measurement of indole-3-acetic acid (IAA) production}

The ability of producing IAA was assessed by colorimetric analysis. For the measurement of IAA production, the tested strains were grown in $20 \mathrm{~mL}$ King B broth medium (per liter: peptone, $20 \mathrm{~g} ; \mathrm{K}_{2} \mathrm{HPO}_{4}, 1.15 \mathrm{~g} ; \mathrm{MgSO}_{4} \cdot 7 \mathrm{H}_{2} \mathrm{O}, 1.5 \mathrm{~g}$; glycerol, $10 \mathrm{~g}$ ) supplemented with $100 \mu \mathrm{g} \cdot \mathrm{mL}^{-1} \mathrm{Trp}$ (IAA precursor). The non-cultured medium was used as the negative control and Azospirillum brasilense SP7 was selected as the positive control. The culture supernatants were obtained by centrifuging at $12000 \mathrm{rpm}$ for $10 \mathrm{~min}$. The test strains were measured by colorimetric assay according to the method described by Glickmann et al. (Glickmann \& Dessaux 1995). Briefly, 2 $\mathrm{mL}$ Salkowski reagent containing $4.5 \mathrm{~g} / \mathrm{L} \mathrm{FeCl}_{3}$ in $10.8 \mathrm{M} \mathrm{H}_{2} \mathrm{SO}_{4}$ was mixed with $1 \mathrm{~mL}$ supernatant. Then, the mixture was stired evenly and left in the darkness for $30 \mathrm{~min}$ at room temperature. The production of IAA was measured using spectrophotometer (Shimadzu UVmini1240, Japan) at $530 \mathrm{~nm}$. Each treatment had three biological replicates.

\section{Evaluation of plant growth-promoting effect}

The tested strains were evaluated for their potential to promote plant growth on wheat cultivar Jimai 22 (Shandong Runfeng Seed Industry Co., Ltd), cucumber Zhongnong 8 (Beijing Shengfeng Garden Agricultural Technology Co., Ltd) and tomato Jiafen 15 (Tianjin Xingke Seed Co., Ltd) seedlings in the greenhouse of China Agricultural University, Beijing, China. The lengths and dry weights of three plants inoculated with strains were determined by the procedure described by Li et al. (Li et al. 2017).

For preparing the bacterial cultures, each isolate was grown $150 \mathrm{~mL}$ LB broth medium for 24 $\mathrm{h}$ at $30^{\circ} \mathrm{C}$. After incubation, the cells were harvested by centrifugation at $6000 \mathrm{rpm}$ for $5 \mathrm{~min}$ at 
171

172

173

174

room temperature. The cell pellet was washed with sterile water and then adjusted to $10^{8}$ cells $\cdot \mathrm{mL}^{-1}$ with $0.9 \%$ saline solution.

Wheat, cucumber and tomato seeds were sterilized with $10 \%$ sodium hypochlorite for 10 min and washed with sterilized water three times. Then the seeds germinated on sterile wet filter in Petri dishes in the dark at $25^{\circ} \mathrm{C}$ for 5-7 days. After germination, seedlings were soaked in bacterial suspensions $\left(10^{8}\right.$ cells $\left.\cdot \mathrm{mL}^{-1}\right)$ for $15 \mathrm{~min}$. Then three seedlings of different plants were transplanted into 12-cm-diam pots containing in the medium of turfy soil (Beijing Jixiang Feiyun Garden Engineering Co., Ltd. Cat. \#101G) : vermiculite (Beijing Jixiang Feiyun Garden Engineering Co., Ltd. Cat. \#GM010108) of $1: 1$, and grown in the greenhouse $\left(16 \mathrm{~h}\right.$ day $/ 8 \mathrm{~h}$ night and $22^{\circ} \mathrm{C} / 10^{\circ} \mathrm{C}$ day/night temperature). Each treatment had three pots. Two weeks later, each of the seedlings was watered with $15 \mathrm{~mL}$ bacterial suspensions $\left(10^{8}\right.$ cells $\left.\cdot \mathrm{mL}^{-1}\right)$ again. The un-inoculated seedlings were used as negative controls, while the un-inoculated seedlings watered with nitrogen fertilizer (83 $\mathrm{mg} \mathrm{N} \cdot \mathrm{kg}^{-1}$ soil) were set as positive controls (Li et al. 2019). After five-week growth, the plants were harvested and the roots were washed carefully with running water to remove the adherent soil. The lengths of the shoot and root and dry weights of the shoot and root were recorded and statistically analyzed, respectively.

\section{Statistical analysis}

Each treatment had three replicates. Statistical analysis was performed using SPSS 20.0 (SPSS, Chicago, IL, USA). Means of different treatments were compared using the least significant difference (LSD) at 0.05 level of probability.

\section{Ethics approval and consent to participate}


Not applicable.

193

\section{Results}

\section{The nifH gene analysis and nitrogenase activity assay}

Nitrogenase is comprised of two component proteins: Fe protein and MoFe protein (Mus et al. 2018). The Fe protein is encoded by nifH gene, and MoFe protein is encoded by nifD and nifK genes. The conserved nifH gene has been exploited to screen the genetic potential for nitrogenfixing bacteria in the environment (Ding et al. 2005; Mehta et al. 2003).

In this study, 179 strains were isolated by using nitrogen-free medium after heating at at $85^{\circ} \mathrm{C}$ for 10 min from 69 soil samples collected from different plant rhizospheres in different areas. PCR amplification of nifH gene (encoding Fe protein of nitrogenase) with universal primers was conducted using genomic DNA extracted from above bacteria. The results showed that a nifH gene fragment of 323 nucleotides was detected in 25 isolates (Table 1). The PCR-amplified nifH gene fragments from 25 isolates were sequenced and their predicted amino acid sequences of NifH were aligned with the NifH sequences from other diazotrophs. The results showed that all of them except for Paenibacillus sp. HN-1 shared 84\%-99\% NifH sequence identity with other Paenibacillus strains. The sequencing result of Paenibacillus sp. HN-1 nifH fragment displayed double peaks, which indicated that there were multiple nifH genes in its genome.

As displayed in Table 1, all of the 25 strains with nifH genes had nitrogenase activities with variation from 57.23 to $11868.65 \mathrm{nmol} \mathrm{C}_{2} \mathrm{H}_{4} \cdot \mathrm{mg}^{-1}$ protein $\cdot \mathrm{h}^{-1}$. Paenibacillus $\mathrm{sp}$. SZ-1b presented the highest nitrogenase activity $\left(11868.65 \mathrm{nmol} \mathrm{C}_{2} \mathrm{H}_{4} \cdot \mathrm{mg}^{-1}\right.$ protein $\left.\cdot \mathrm{h}^{-1}\right)$. Paenibacillus $\mathrm{sp}$. SZ13a, Paenibacillus sp. SZ-13b, Paenibacillus sp. YN-3, Paenibacillus sp. AH-4, Paenibacillus sp. JS-4 and Paenibacillus sp. CD-4b had higher nitrogenase activities (> $3000 \mathrm{nmol} \mathrm{C}_{2} \mathrm{H}_{4} \cdot \mathrm{mg}^{-1}$ 
214 protein $\left.\cdot \mathrm{h}^{-1}\right)$. The nitrogenase activity, cell morphology, colony morphology, GenBank accession

215 number and origin/location were listed in Table 1.

216 Sequencing and phylogeny of 16S rRNA

217 The 16S rRNA gene sequence is named as the evolution clock of bacterial phylogeny because 218 of high conservation and slow evolution, which is widely used in identification of bacteria (Roller 219 et al. 1994; Vandamme et al. 1996). The 16S rRNA gene sequences of the 25 strains were 220 compared with the datebase reserved in GenBank (https://www.ncbi.nlm.nih.gov/genbank/). The 221 alignment results indicated all of the isolates were Paenibacillus. The GenBank accession numbers 222 of them after the bacterial names were shown in Table 1.

A phylogenetic tree was constructed based on $16 \mathrm{~S}$ rRNA sequence, which branched into 5 clusters on the basis of the distance data. The cluster I totally including 17 isolates formed a larger cluster with P. polymyxa, Paenibacillus jamilae and Paenibacillus peoriae. Among the 17 isolates, 6 isolates exhibited $99.2 \%-99.6 \% 16 \mathrm{~S}$ rRNA sequence similarities with $P$. polymyxa. 7 isolates had the highest similarities with $P$. jamilae, and 4 isolates showed particularly high homologies with $P$. peoriae $(>99.5 \%)$. The cluster II contained 3 isolates, which displayed the highest similarity with Paenibacillus brasilensis, ranging from $99 \%$ to $99.2 \%$. The cluster III only included Paenibacillus sp. CD-4a, which had highest 16S rRNA sequence similarity with Paenibacillus jilunlli (99.6\%). The cluster IV which consisted of 2 strains clustered with Paenibacillus zanthoxyli showing $99.3 \%$ to $99.6 \% 16 \mathrm{~S}$ rRNA sequence similarities with $P$. zanthoxyli. The cluster V covering 2 isolates formed a monophyletic cluster with Paenibacillus stellifer bacteria, and their 16S rRNA sequences similarities with $P$. stellifer were above 99\%.

\section{Antibacterial capacity determination}


In the study, all 25 Paenibacillus strains were tested against 6 plant pathogens. The results

237 (Table 2) showed that 21 bacteria presented antibiosis, inhibiting at least one of the 6 indicator

238

239

240

241

242

243

244 phytopathogens. Out of them, 18 bacteria could inhibit 5 plant pathogens (R. cerealis, $F$. graminearum, G. zeae, C. gossypii and A. longipes). Furthermore, Paenibacillus sp. SZ-13b exhibited an extremely good antibiotic activity, which was able to inhibit the growth of all indicator phytopathogens. The growth of $F$. graminearum was strongly inhibited, showing the average inhibition zones larger than $25 \mathrm{~mm}$. While the growth of $F$. solani was weakly inhibited, which was only inhibited by two strains (Paenibacillus sp. SZ-13b and Paenibacillus sp. BJ-6) with the inhibition zones around 5 and $15 \mathrm{~mm}$. In addition, Paenibacillus sp. AH-3, Paenibacillus sp. HN1, Paenibacillus sp. CD-4a and Paenibacillus sp. CD-4b could not exhibit any antibiotic effect on 6 indicator fungi.

In general, out of the 25 tested strains, $80 \%$ strains presented antimicrobial activity against plant pathogens, with average inhibition zones varying from 15 to $35 \mathrm{~mm}$. Combination with their phylogeny of $16 \mathrm{~S}$ rRNA, the isolates with inhibition flocked together, which were particularly close to P. polymyxa and its highly close species (Fig. 1).

\section{Assessment of IAA production and plant growth promoting traits}

IAA is an essential plant hormone regulating the growth and development of plants. In this study, we determined the ability of producing IAA for all strains. Fig. 2 showed that besides Paenibacillus sp. AH-1, Paenibacillus sp. CD-4a and Paenibacillus sp. CD-4b, the rest of tested strains were capable of producing IAA. Out of them, Paenibacillus sp. WF-6 produced the highest yield of IAA (7.19 $\left.\mathrm{mg} \cdot \mathrm{L}^{-1}\right)$. In addition, the other 9 bacteria (Paenibacillus sp. BJ-2, Paenibacillus sp. SZ-1a, Paenibacillus sp. SZ-1b, Paenibacillus sp. BJ-4, Paenibacillus sp. BJ-5, Paenibacillus 
258 sp. BJ-6, Paenibacillus sp. YN-3, Paenibacillus sp. YB-3, Paenibacillus sp. JS-4) could yield 259 relatively high amount of IAA $\left(>4 \mathrm{mg} \cdot \mathrm{L}^{-1}\right)$.

260 According to above results of nitrogenase activities, antibacterial capacities and IAA 261 production, we chose 8 strains (Paenibacillus sp. SZ-1b, Paenibacillus sp. BJ-4, Paenibacillus sp. 262 SZ-10, Paenibacillus sp. SZ-13b, Paenibacillus sp. SZ-14, Paenibacillus sp. YB-3, Paenibacillus 263 sp. WF-6, Paenibacillus sp. JS-4) to assess their capabilities of promoting growth of plants (wheat, 264 cucumber and tomato). Inoculation of plants with some Paenibacillus isolates appeared to promote 265 plant growth including plant height and dry weight (Fig. 3 and Fig. 4). As shown in Fig. 4A, wheat 266 seedlings inoculated with Paenibacillus sp. JS-4 led to a maximum increase (30.9\%) in shoot 267 length, followed by Paenibacillus sp. SZ-1b (23.3\%) and Paenibacillus sp. BJ-4 (22.3\%). While 268 inoculation with Paenibacillus sp. SZ-14 yielded a maximum increase $(54.2 \%)$ in root length, 269 followed by Paenibacillus sp. JS-4 (18.2\%). Inoculation of wheat plants with Paenibacillus sp. JS-4 showed a greatly significant increase in shoot and root dry weights. Besides, Paenibacillus sp. BJ-4 and Paenibacillus sp. SZ-10 had higher dry weights of shoot and root as compared to the controls (Fig. 4B). The effects of these two bacteria on wheat seedlings were equal to the positive

273 control with chemical nitrogen fertilizer. In Fig. 4C, cucumber seedlings inoculated with Paenibacillus sp. SZ-10 resulted in the highest heights both in shoot (50.0\%) and in root (94.4\%), followed by Paenibacillus sp. SZ-14 (33.7\% and 38.7\%, respectively) and Paenibacillus sp. WF6 (18.4\% and 62.4\%, respectively). In addition, inoculation with Paenibacillus sp. SZ-10 presented the highest increase in dry weights of shoot and root of eight selected isolates, which showed more significant effect on cucumber seedlings than the positive control. And inoculation with Paenibacillus sp. SZ-14 had the second highest increase in total dry weight (Fig. 4D), which was 280 the same as the positive control with chemical nitrogen fertilizer. Overall, Paenibacillus sp. SZ- 
28110 showed significant growth-promoting effects on the cucumber plants. As shown in Fig. 4E and

282 F, most isolates could promote growth of tomato. Out of them, inoculation with Paenibacillus sp.

283 BJ-4 presented to enhance development of tomato length, both in shoot $(64.6 \%)$ and in root 284 (55.2\%) (Fig. 4E). And inoculation with Paenibacillus sp. SZ-15 displayed maximum increases in 285 shoot and root dry weights (Fig. 4F), which showed more promotive effect on shoot dry weight of 286 tomato than the positive control.

287

288 Discussion

289 Paenibacillus species are ubiquitous in nature, and they are capable to form resistant 290 endospores to allow them surviving in a wide range of environmental variables and to enhance 291 plant growth by several mechanisms (Bloemberg \& Lugtenberg 2001). In this study, 179 bacterial 292 strains were isolated by their growth on nitrogen-free medium from plant rhizosphere all over 293 China. 16S rRNA sequence analysis showed that 25 of 179 bacteria belong to Paenibacillus genus.

294 We revealed that 25 Paenibacillus strains had the nifH gene encoding the Fe protein of Mo295 nitrogenase. Also, the 25 Paenibacillus strains exhibited nitrogenase activities. These results 296 demonstrated that the $25 \mathrm{~N}_{2}$-fixing Paenibacillus strains could provide nitrogen for plants. 297 Phylogenetic analysis showed that the $25 \mathrm{~N}_{2}$-fixing Paenibacillus strains were divided into five 298 clusters. 20 of the $25 \mathrm{~N}_{2}$-fixing Paenibacillus strains were in cluster I and cluster II that were 299 closely related to $P$. polymyxa, $P$. jamilae, $P$. peoriae, and $P$. brasilensis. The other five $\mathrm{N}_{2}$-fixing 
300

301

302

303

304

305

306

307

308

309

310

311

312

313

314

315

316

317

318

319

320

Paenibacillus strains belonged to cluster III, cluster IV and cluster V (including P. jilunlii, $P$.

zanthoxyli, and P. stellifer mainly).

In this study, 20 of the $25 \mathrm{~N}_{2}$-fixing Paenibacillus strains had inhibitory effects against plant

pathogenic fungi, with average inhibition zones varying from 15 to $35 \mathrm{~mm}$ on plate. Especially,

Paenibacillus sp. SZ-13b could suppress 6 tested bacterial plant pathogens. Wherease,

Paenibacillus sp. SZ-1b, Paenibacillus sp. SZ-15, and Paenibacillus sp. JS-4 could suppress 5

tested bacterial plant pathogens with strong inhibition activities. The 20 strains with inhibitory

effects against plant pathogenic fungi belonged to cluster I and cluster $\mathbb{I}$ that were closely related to $P$. polymyxa, $P$. jamilae, $P$. peoriae, and $P$. brasilensis. Our results are consistent with the previous results that $P$. polymyxa have long been known for their great ability to produce peptide antibiotics to suppress the growth of plant pathogenic fungi (Deng et al. 2011; He et al. 2007; Helbig 2001; Raza et al. 2008). For examples, P. polymyxa M1 (HE577054), which was isolated from root tissues of wheat, was able to promote wheat growth and suppress several phytopathogens (Niu et al. 2011; Yao et al. 2008). P. polymyxa SQR-21 (CP006872) selected from the rhizosphere soil of watermelon could significantly inhibit $F$. oxysporum (Raza et al. 2009). P. brasilensis PB1 72 (NR025106) isolated from the maize rhizosphere was able to protect seeds and roots against phytopathogenic fungi (Fusarium moniliforme and Diplodia macrospora) (von der Weid et al. 2005; von der Weid et al. 2002).

Additionally, $22 \mathrm{~N}_{2}$-fixing Paenibacillus strains (except for Paenibacillus sp. AH-1, Paenibacillus sp. CD-4a and Paenibacillus sp. CD-4b) were capable of producing IAA, which is a primary plant hormone regulating plant growth and development. Among them, Paenibacillus 
321 sp. WF-6, Paenibacillus sp. SZ-1a, Paenibacillus sp. SZ-1b, Paenibacillus sp. BJ-5, Paenibacillus

322 sp. YB-3 generated higher yield of IAA.

323 According to the results of nitrogenase activity, IAA level and inhibitory effect against plant 324 pathogens, 8 strains were chosen to inoculate wheat seedlings, cucumber seedlings and tomato 325 seedlings to analyse their plant promotion effects. We found that Paenibacillus sp. JS-4 and 326 Paenibacillus sp. BJ-4 promoted wheat growth as well as the chemical nitrogen fertilizer did. 327 While Paenibacillus sp. SZ-10 and Paenibacillus sp. SZ-14 promoted cucumber growth as well 328 as the chemical nitrogen fertilizer did. The 2 strains Paenibacillus sp. SZ-15 and Paenibacillus sp. BJ-4 significantly promoted tomato growth. Moreover, the 4 strains including Paenibacillus sp. SZ-10, Paenibacillus sp. SZ-14, Paenibacillus sp. YB-10, and Paenibacillus sp. WF-6 could promote tomato growth. From these results, we found that the plant promotion effects exhibited by a Paenibacillus strain varied among plants. At present, we do not know why a same Paenibacillus strain had different promotion effects on different plants. Paenibacillus sp. BJ-4 and Paenibacillus sp. SZ-15 with the significant effects of promoting plant growth have great potential as bio-fertilizer.

Microbial fertilizers are widely used in plantation of vegetables in China. The members of are usually used in biofertilizers. The Paenibacillus strains with nitrogen fixation and multiple bacterial properties for promoting plant growth obtained in this study have great potential to be developed as biofertilizers. 
344 Conclusion

345 In conclusion, $25 \mathrm{~N}_{2}$-fixing Paenibacillus strains were isolated from plant rhizospheres. Most 346 of them possessed multiple beneficial properties and characteristics of PGPR. They could fix 347 atmospheric nitrogen, produce the profitable phytohormone IAA, control against a wide set of 348 plant pathogens, and enhance growth of diverse important plants. Especially, the 5 strains 349 including Paenibacillus sp. JS-4, Paenibacillus sp. SZ-10, Paenibacillus sp. SZ-14, Paenibacillus 350 sp. BJ-4 and Paenibacillus sp. SZ-15 with the significant effects of promoting plant growth could 351 be developed and commercially formulated to substitute for environmentally harmful chemical 352 fertilizer and pesticides in field experiments.

Figure captions

357

358

359

360

361

362

Figure 1: Neighbour-joining phylogenetic tree based on 16S rRNA sequence showing the position of isolated strains with other closely related strains of the genus Paenibacillus in GenBank. The tree was structured using neighbor joining method, with the bootstrap percentage values obtained from 1000 cycles. Only bootstrap values greater than 50\% are shown at the branching points. Bar, 0.005 substitutions per nucleotide position. Isolated strains in this study are underlined with the bold letters. 
363 Figure 2: Qualitative analysis of IAA production by isolated strains. Data are means \pm SE of 364 three independent biological replicates. Bearing different alphabets are significantly different 365 from each other according to the LSD test $(p<0.05)$.

366 Figure 3: Plant growth promotion by some Paenibacillus strains. (A) Wheat seedlings 367 inoculated with Paenibacillus sp. JS-4; (B) Cucumber seedlings inoculated with Paenibacillus 368 sp. SZ-10; (C) Tomato seedlings inoculated with Paenibacillus sp. SZ-15.

Figure 4: Effects of eight selected strains inoculation on shoot and root length of wheat (A), dry weight of wheat (B), on shoot and root length of cucumber (C), dry weight of cucumber (D), on shoot and root length of tomato (E), dry weight of tomato (F). Control: un-inoculated seedlings. Date represent the means $\pm \mathrm{SE}$ of 3 independent biological replicates. In the root group or shoot group, bearing different alphabets are significantly different from each other

374 according to the LSD test $(p<0.05)$.

\section{Table captions}

Table 1: Characterization and nitrogenase activity of isolates.

Table 2: Antimicrobial activity of Paenibacillus isolates, which inhibit 6 indicator bacteria. 


\section{References}

Ash C, Priest FG, and Collins MD. 1993. Molecular identification of rRNA group 3 bacilli (Ash, Farrow, Wallbanks and Collins) using a PCR probe test. Proposal for the creation of a new genus Paenibacillus. Antonie Van Leeuwenhoek 64:253.

Cho KM, Hong SY, Lee SM, Kim YH, Kahng GG, Lim YP, Kim H, and Yun HD. 2007. Endophytic bacterial communities in ginseng and their antifungal activity against pathogens. Microbial Ecology 54:341-351 DOI 10.1007/s00248-007-9208-3.

Curatti L, and Rubio LM. 2014. Challenges to develop nitrogen-fixing cereals by direct nif-gene transfer. Plant Science 225:130-137 DOI 10.1016/j.plantsci.2014.06.003 .

Da Mota FFG, Eliane Aparecida, and Seldin L. 2008. Auxin production and detection of the gene coding for the Auxin Efflux Carrier (AEC) protein in Paenibacillus polymyxa. Journal of Microbiology 46:257-264 DOI 10.1007/s12275-007-0245-x.

Deng Y, Lu Z, Bi H, Lu F, Zhang C, and Bie X. 2011. Isolation and characterization of peptide antibiotics LI-F04 and polymyxin B produced by Paenibacillus polymyxa strain JSa-9. 
410

411

412

413

414

415

416

417

418

419

420

421

422

423

424

425

426

427

428

429

430

431

432

433

434

435

436

437

438

439

440

441

442

443

444

445

446

447

448

449

450

Peptides 32:1917-1923 DOI 10.1016/j.peptides.2011.08.004.

Ding Y, Wang J, Liu Y, and Chen S. 2005. Isolation and identification of nitrogen-fixing bacilli from plant rhizospheres in Beijing region. Journal of Applied Microbiology 99:1271 DOI 10.1111/j.1365-2672.2005.02738.x.

Erisman JW, Sutton MA, Galloway J, Klimont Z, and Winiwarter W. 2008. How a century of ammonia synthesis changed the world. Nature Geoscience 1:636-639 DOI 10.1038/ngeo325.

Fang XM, Li YS, Nie J, Wang C, Huang KH, Zhang YK, Zhang YL, She HZ, Liu XB, and Ruan RW. 2018. Effects of nitrogen fertilizer and planting density on the leaf photosynthetic characteristics, agronomic traits and grain yield in common buckwheat (Fagopyrum esculentum M.). Field Crops Research 219:160-168 DOI 10.1016/j.fcr.2018.02.001.

Fortes TO, Alviano DS, Tupinambá G, Padrón TS, Antoniolli AR, Alviano CS, and Seldin L. 2008. Production of an antimicrobial substance against Cryptococcus neoformans by Paenibacillus brasilensis Sa3 isolated from the rhizosphere of Kalanchoe brasiliensis. Microbiological Research 163:200-207 DOI 10.1016/j.micres.2006.05.003.

Garcia J, and Kao-Kniffin J. 2018. Microbial group dynamics in plant rhizospheres and their implications on nutrient cycling. Frontiers in Microbiology 9:1516 DOI 10.3389/fmicb.2018.01516.

Glickmann E, and Dessaux Y. 1995. A critical examination of the specificity of the salkowski reagent for indolic compounds produced by phytopathogenic bacteria. Applied and Environmental Microbiology 61:793 DOI 10.0000/PMID16534942.

Graham PH, Vance CP, Graham PH, and Vance CP. 2000. Nitrogen fixation in perspective: an overview of research and extension needs. Field Crops Research 65:93-106 DOI 10.1016/S0378-4290(99)00080-5.

Grau FH, and Wilson PW. 1962. Physiology of nitrogen fixationby Bacillus polymyxa. Journal of Bacteriology 83:490-496.

He ZG, Kisla D, Zhang LW, Yuan CH, Green-Church KB, and Yousef AE. 2007. Isolation and identification of a Paenibacillus polymyxa strain that coproduces a novel lantibiotic and polymyxin. Applied and Environmental Microbiology 73:168-178 DOI 10.1128/AEM.02023-06.

Helbig J. 2001. Biological control of botrytis cinerea Pers. ex Fr. in strawberry by Paenibacillus polymyxa. Journal of Phytopathology 149:265-273 DOI 10.1046/j.14390434.2001.00371.X.

Hong YY, Ma YC, Zhou YG, Gao F, Liu HC, and Chen SF. 2009. Paenibacillus sonchi sp. nov., a nitrogen-fixing species isolated from the rhizosphere of Sonchus oleraceus. International Journal of Systematic \& Evolutionary Microbiology 59:2656-2661 DOI 10.1099/ijs.0.009308-0.

Ivleva NB, Jeanna G, Staub JM, and Michael S. 2016. Expression of active subunit of nitrogenase via integration into plant organelle genome. PloS One 11:e0160951 DOI 10.1371/journal.pone.0160951 DOI 10.1371/journal.pone.0160951.

Jiao XQ, He G, Cui ZL, Shen JB, and Zhang FS. 2018. Agri-environment policy for grain 
451

452

production in China: toward sustainable intensification. China Agricultural Economic Review 10:00-00 DOI 10.1108/CAER-10-2017-0201.

Jin HJ, Lv J, and Chen SF. 2011. Paenibacillus sophorae sp. nov., a nitrogen-fixing species isolated from the rhizosphere of Sophora japonica. International Journal of Systematic and Evolutionary Microbiology 61:767-771 DOI 10.1099/ijs.0.021709-0.

Khan AL, Waqas M, Kang SM, Alharrasi A, Hussain J, Alrawahi A, Alkhiziri S, Ullah I, Ali L, and Jung HY. 2014. Bacterial endophyte Sphingomonas sp. LK11 produces gibberellins and IAA and promotes tomato plant growth. Journal of Microbiology 52:689-695 DOI 10.1007/s12275-014-4002-7.

Li J, Beatty PK, Shah S, and Jensen SE. 2007. Use of PCR-targeted mutagenesis to disrupt production of fusaricidin-type antifungal antibiotics in Paenibacillus polymyxa. Applied Environmental Microbiology 73:3480-3489 DOI 10.1128/AEM.02662-06.

Li Y, Li Y, Zhang H, Wang M, and Chen S. 2019. Diazotrophic Paenibacillus beijingensis BJ18 provides nitrogen for plant and promotes plant growth, nitrogen uptake and metabolism. Frontiers in Microbiology 10:1119 DOI 10.3389/fmicb.2019.01119.

Li Y, Liu X, Hao T, and Chen S. 2017. Colonization and maize growth promotion induced by phosphate solubilizing bacterial isolates. International Journal of Molecular Sciences $\mathbf{1 8}$ DOI 10.3390/ijms 18071253.

Ma Y, Xia Z, Liu X, and Chen S. 2007. Paenibacillus sabinae sp. nov., a nitrogen-fixing species isolated from the rhizosphere soils of shrubs. International Journal of Systematic \& Evolutionary Microbiology 57:6-11 DOI 10.1099/ijs.0.64519-0.

Ma YC, and Chen SF. 2008. Paenibacillus forsythiae sp. nov., a nitrogen-fixing species isolated from rhizosphere soil of Forsythia mira. International Journal of Systematic \& Evolutionary Microbiology 58:319-323 DOI 10.1099/ijs.0.65238-0.

Mehta MP, Butterfield DA, and Baross JA. 2003. Phylogenetic diversity of nitrogenase (nifH) genes in deep-sea and hydrothermal vent environments of the Juan de Fuca Ridge. Applied Environmental Microbiology 69:960 DOI 10.1128/AEM.69.2.960-970.2003.

Mohamed I, Eid KE, Abbas MHH, Salem AA, Ahmed N, Ali M, Shah GM, and Fang C. 2019. Use of plant growth promoting Rhizobacteria (PGPR) and mycorrhizae to improve the growth and nutrient utilization of common bean in a soil infected with white rot fungi. Ecotoxicology and Environmental Safety 171:539-548 DOI 10.1016/j.ecoenv.2018.12.100.

Mus F, Alleman AB, Pence N, Seefeldt LC, and Peters JW. 2018. Exploring the alternatives of biological nitrogen fixation. Metallomics 10 DOI 10.1039/C8MT00038G.

Navarronoya YE, Hernándezmendoza E, Moralesjiménez J, Janroblero J, Martínezromero E, and Hernándezrodríguez C. 2012. Isolation and characterization of nitrogen fixing heterotrophic bacteria from the rhizosphere of pioneer plants growing on mine tailings. Applied Soil Ecology 62:52-60 DOI 10.1016/j.apsoil.2012.07.011.

Neilands JB. 1993. Siderophores. Archives of Biochemistry \& Biophysics 302:1-3 DOI 10.1006/abbi.1993.1172.

Niu B, Rueckert C, Blom J, Wang Q, and Borriss R. 2011. The genome of the plant growthpromoting rhizobacterium Paenibacillus polymyxa M-1 contains nine sites dedicated to 
492

493

494

495

496

497

498

499

500

501

502

503

504

505

506

507

508

509

510

511

512

513

514

515

516

517

518

519

520

521

522

523

524

525

526

527

528

529

530

531

532

nonribosomal synthesis of lipopeptides and polyketides. Journal of Bacteriology 193:58625863 DOI 10.1128/JB.05806-11.

Raza W, Yang W, and Shen QR. 2008. Paenibacillus polymyxa: antibiotics, hydrolytic enzymes and hazard assessment Journal of Plant Pathology 90:419-430 DOI 10.2307/41998534.

Raza W, Yang XM, Wu HS, Wang Y, Xu YC, and Shen QR. 2009. Isolation and characterisation of fusaricidin-type compound-producing strain of Paenibacillus polymyxa SQR-21 active against Fusarium oxysporum f.sp. nevium. European Journal of Plant Pathology 125:471-483 DOI 10.1007/s10658-009-9496-1.

Reay DS, Davidson EA, Smith KA, Smith P, Melillo JM, Dentener F, and Crutzen PJ. 2012. Global agriculture and nitrous oxide emissions. Nature Climate Change 2:410-416 DOI 10.1038/nclimate1458.

Roller C, Wagner M, Amann R, Ludwig W, and Schleifer KH. 1994. In situ probing of Grampositive bacteria with high DNA G + C content using 23S rRNA-targeted oligonucleotides. Microbiology 140:2849-2858 DOI 10.1099/00221287-140-10-2849.

Seldin L. 2011. Paenibacillus, nitrogen fixation and soil fertility. N.A. Logan and P. De Vos (eds.), Endospore-forming Soil Bacteria, Soil Biology 27 DOI 10.1007/978-3-642-19577-8_15.

Seldin L, Elsas JDV, and Penido EGC. 1984. Bacillus azotofixans sp. nov. a nitrogen-fixing species from Brazilian soils and grass roots. International Journal of Systematic Bacteriology 34:451-456.

Tamura K, Stecher G, Peterson D, Filipski A, and Kumar S. 2013. MEGA6: Molecular evolutionary genetics analysis version 6.0. Molecular Biology \& Evolution 30:2725-2729 DOI 10.1093/molbev/mst197.

Tayefeh M, Sadeghi SM, Noorhosseini SA, Bacenetti J, and Damalas CA. 2018. Environmental impact of rice production based on nitrogen fertilizer use. Environmental Science Pollution Research 25:1-11 DOI 10.1007/s11356-018-1788-6.

Timmusk S, Van West P, Gow NA, and Huffstutler RP. 2009. Paenibacillus polymyxa antagonizes oomycete plant pathogens Phytophthora palmivora and Pythium aphanidermatum. Journal of Applied Microbiology 136:S265-S266 DOI 10.1111/j.13652672.2009.04123.x.

Vandamme P, Pot B, Gillis M, Vos P, De, Kersters K, and Swings J. 1996. Polyphasic taxonomy, a consensus approach to bacterial systematics. . Microbiological Reviews 60:407 DOI 10.1006/mpat.1996.0035.

Verma RK, Sachan M, Vishwakarma K, Upadhyay N, Mishra RK, Tripathi DK, and Sharma S. 2018. Role of PGPR in sustainable agriculture: molecular approach toward disease suppression and growth promotion. DOI 10.1007/978-981-13-0044-8_9.

von der Weid I, Artursson V, Seldin L, and Jansson JK. 2005. Antifungal and root surface colonization properties of GFP-tagged Paenibacillus brasilensis PB177. World Journal of Microbiology \& Biotechnology 21:1591-1597 DOI 10.1007/s11274-005-8123-3.

von der Weid I, Duarte GF, van Elsas JD, and Seldin L. 2002. Paenibacillus brasilensis sp. nov., a novel nitrogen-fixing species isolated from the maize rhizosphere in Brazil. International Journal of Systematic \& Evolutionary Microbiology 52:2147-2153 DOI

Peerj reviewing PDF | (2019:03:35859:2:1:NEW 8 Jul 2019) 
10.1099/00207713-52-6-2147.

Wang LY, Li J, Li QX, and Chen SF. 2014. Paenibacillus beijingensis sp. nov., a nitrogenfixing species isolated from wheat rhizosphere soil. Antonie Van Leeuwenhoek 104:675-683 DOI 10.1007/s10482-013-9974-5.

Wang LY, Zhang LH, Liu ZZ, Zhao DH, Liu XM, Zhang B, Xie JB, Hong YY, Li PF, Chen SF, Dixon R, Li JL. 2013. A minimal nitrogen fixation gene cluster from Paenibacillus sp. WLY78 enables expression of active nitrogenase in Escherichia coli. PLoS Genetics 9:e1003865 DOI 10.1371/journal.pgen.1003865.

Wang TS, Zhao XY, Shi HW, Sun L, Li YB, Li Q, Zhang HW, Chen SF, and Li JL. 2018. Positive and negative regulation of transferred nif genes mediated by indigenous GlnR in Gram-positive Paenibacillus polymyxa. PLoS Genetics 14: e1007629 DOI 10.1371/journal.pgen.1007629.

Weselowski B, Nathoo N, Eastman AW, Macdonald J, and Yuan ZC. 2016. Isolation, identification and characterization of Paenibacillus polymyxa CR1 with potentials for biopesticide, biofertilization, biomass degradation and biofuel production. BMC Microbiology 16:244 DOI 10.1186/s12866-016-0860-y.

Witz DF, Detroy RW, and Wilson PW. 1967. Nitrogen fixation by growing cells and cell-free extracts of the Bacillaceae. Archives of Microbiology 55:369-381.

Xie J, Shi H, Du Z, Wang T, Liu X, and Chen S. 2016. Comparative genomic and functional analysis reveal conservation of plant growth promoting traits in Paenibacillus polymyxa and its closely related species. Scientific Reports 6:21329 DOI 10.1038/srep21329.

Xie JB, Zhang LH, Zhou YG, Liu HC, and Chen SF. 2012. Paenibacillus taohuashanense sp. nov., a nitrogen-fixing species isolated from rhizosphere soil of the root of Caragana kansuensis Pojark. Antonie Van Leeuwenhoek 102:735-741 DOI 10.1007/s10482-012-97734.

Yao LJ, Wang Q, Xue-Chi FU, and Mei RH. 2008. Isolation and identification of endophytic bacteria antagonistic to wheat sharp eyespot disease. Chinese Journal of Biological Control.

Zhalnina K, Louie KB, Hao Z, Mansoori N, da Rocha UN, Shi S, Cho H, Karaoz U, Loqué D, Bowen BP, Firestone MK, Northen TR, Brodie EL. 2018. Dynamic root exudate chemistry and microbial substrate preferences drive patterns in rhizosphere microbial community assembly. Nature Microbiology 3:470-480 DOI 10.1038/s41564-018-0129-3. 


\section{Figure 1}

Figure 1:Neighbour-joining phylogenetic tree based on 16S rRNA sequence showing the position of isolated strains with other closely related strains of the genus Paenibacillus in GenBank.

The tree was structured using neighbor joining method, with the bootstrap percentage values obtained from 1000 cycles. Only bootstrap values greater than $50 \%$ are shown at the branching points. Bar, 0.005 substitutions per nucleotide position. Isolated strains in this study are underlined with the bold letters. 


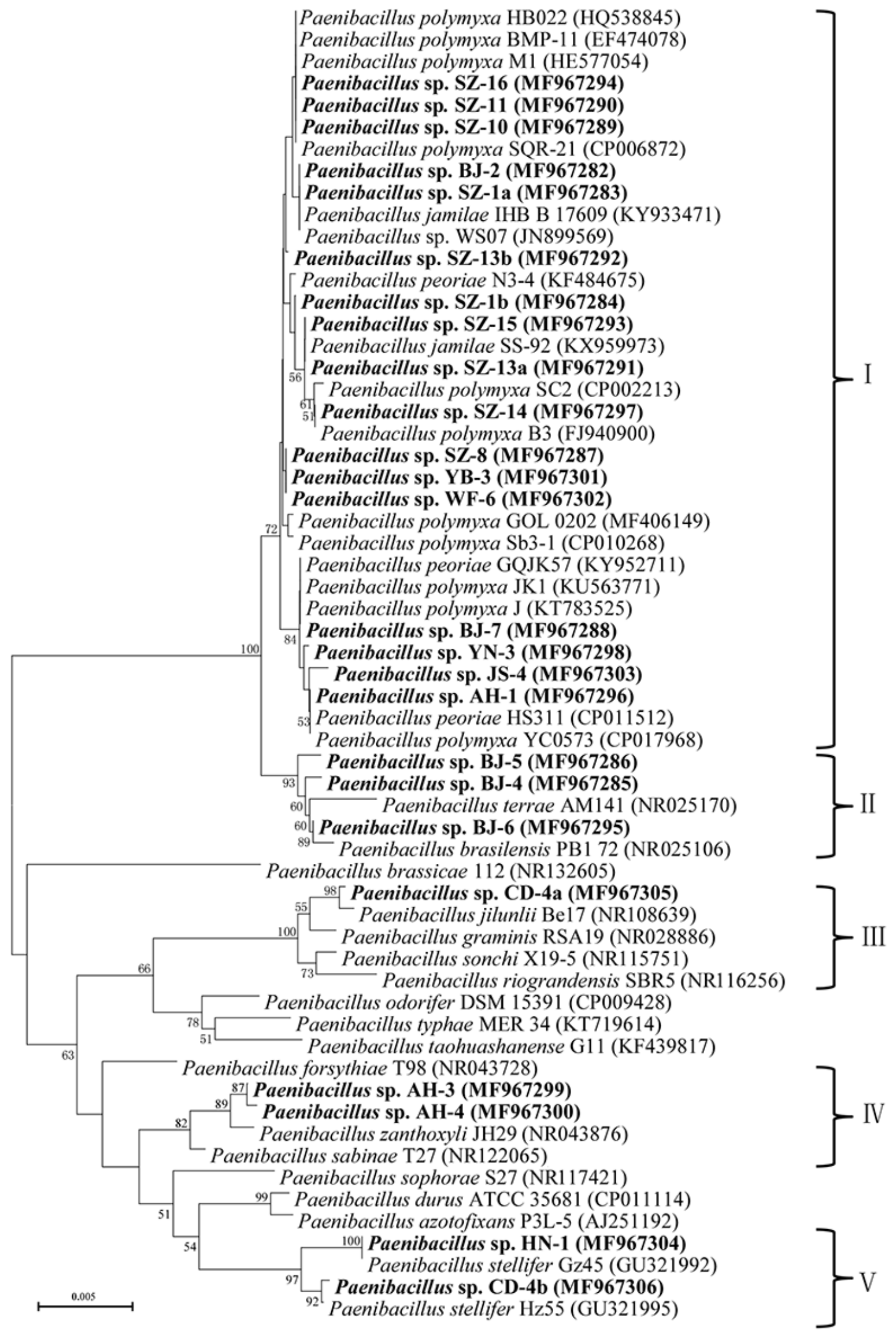


Figure 2

Figure 2: Qualitative analysis of IAA production by isolated strains.

Data are means \pm SE of threeindependent biological replicates. Bearing different alphabets are significantly different from each other according to the LSD test $(p<0.05)$.

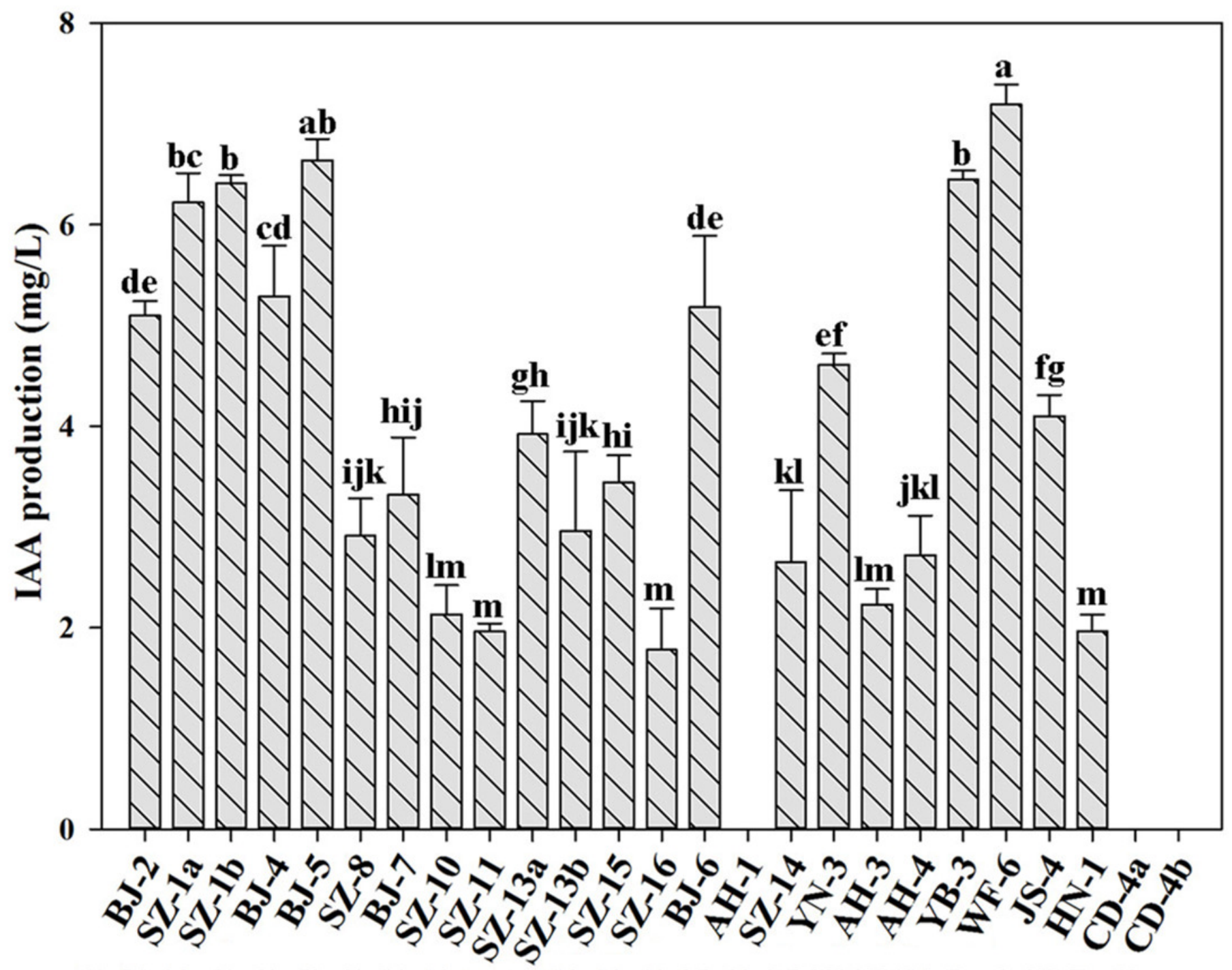


Figure 3

Figure 3: Plant growth promotion by some Paenibacillus strains.

(A) Wheat seedlings inoculated with Paenibacillus sp. JS-4; (B) Cucumber seedlings inoculated with Paenibacillus sp. SZ-10; (C) Tomato seedlings inoculated with Paenibacillus sp. SZ-15.

A
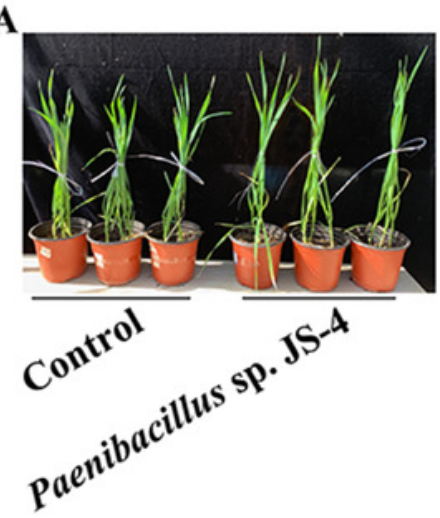

B



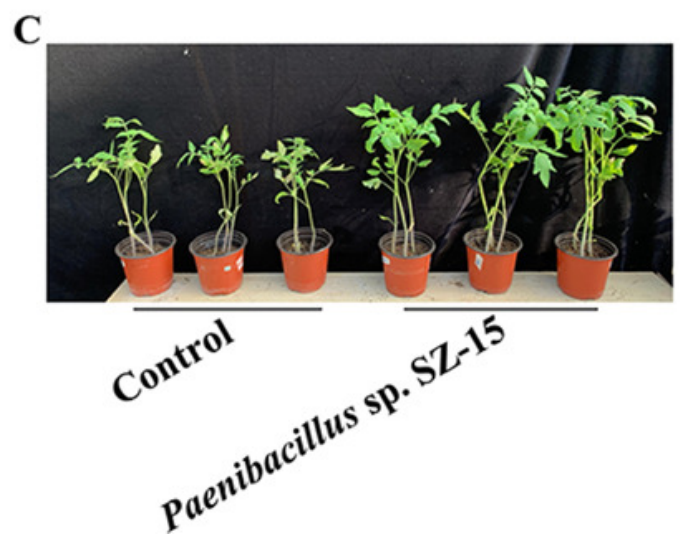




\section{Figure 4}

Figure4: Effects of eight selected strains inoculation on shoot and root length of wheat (A), dry weight of wheat (B), on shoot and root length of cucumber (C), dry weight of cucumber (D), on shoot and root length of tomato (E), dry weight of tomato (F).

Control: un-inoculated seedlings. Date represent the means \pm SE of 3 independent biological replicates. In the root group or shoot group, bearing different alphabets are significantly different from each other according to the LSD test $(p<0.05)$. 
A

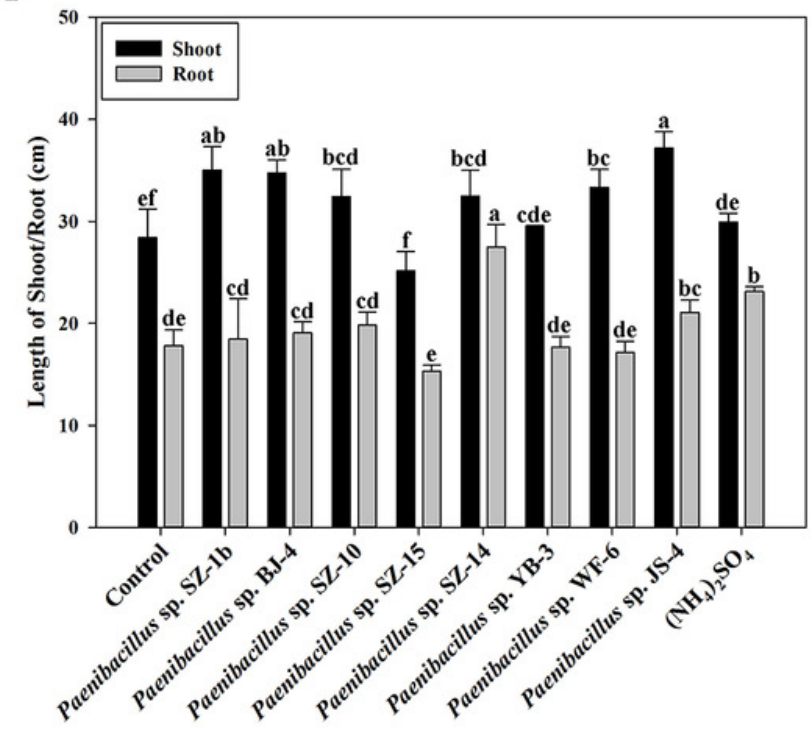

C

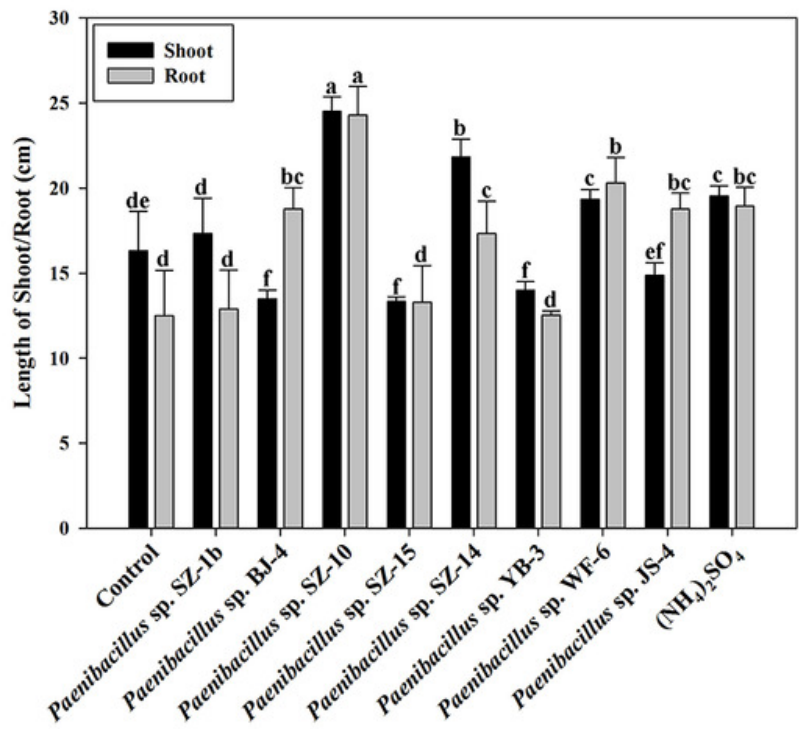

$\mathbf{E}$

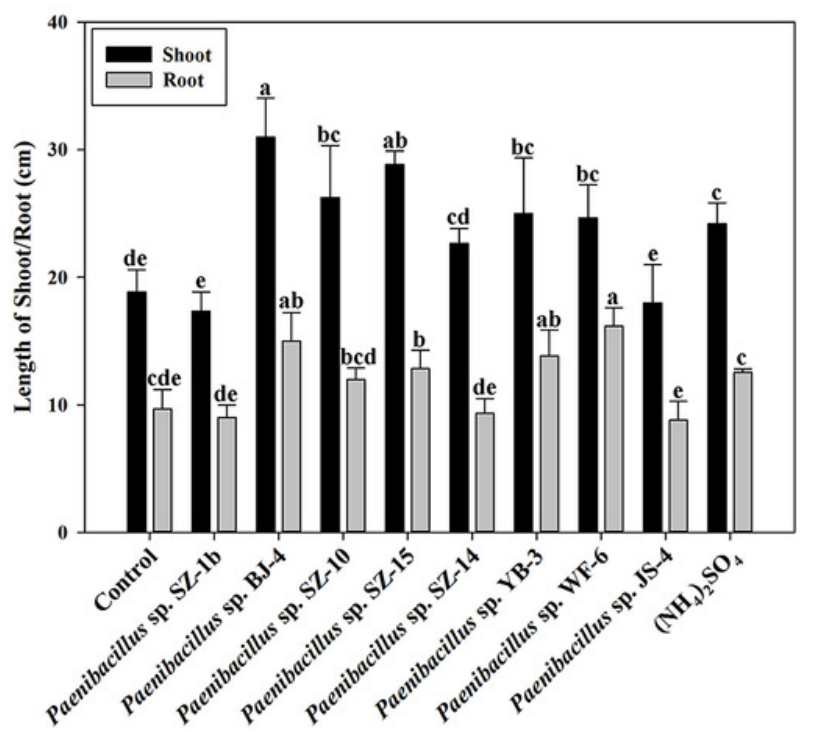

B

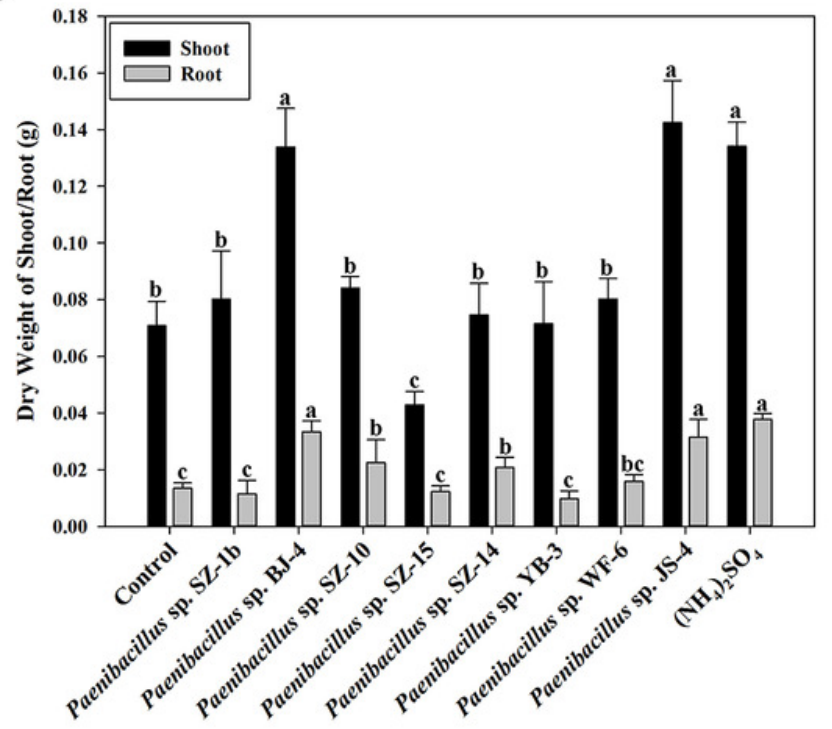

D



F






\section{Table 1 (on next page)}

Characterization and nitrogenase activity of isolates. 
Table1. Characterization and nitrogenase activity of isolates.

\begin{tabular}{|c|c|c|c|c|c|}
\hline Isolates & $\begin{array}{c}\text { Cell } \\
\text { morphology }\end{array}$ & $\begin{array}{l}\text { Colony } \\
\text { morphology }\end{array}$ & $\begin{array}{c}\text { Nitrogenase } \\
\text { activity }^{\mathrm{a}}\end{array}$ & $\begin{array}{c}\text { GenBank } \\
\text { accession } \\
\text { number }\end{array}$ & Origin and Location \\
\hline $\begin{array}{c}\text { Paenibacillus } \\
\text { sp. BJ-2 }\end{array}$ & Rods & Moist, milky & $1085.61 \pm 75.64^{\text {ghi }}$ & MF967282 & $\begin{array}{l}\text { Jujube, mountain in } \\
\text { Huairou, Beijing }\end{array}$ \\
\hline $\begin{array}{c}\text { Paenibacillus } \\
\text { sp. SZ-1a }\end{array}$ & Rods & Moist, milky & $118.65 \pm 3.97^{\mathrm{k}}$ & MF967283 & $\begin{array}{l}40^{\circ} 32^{\prime} \mathrm{N}, 116^{\circ} 62^{\prime} \mathrm{E} \\
\text { Maize, farmland in } \\
\text { Changping, Beijing } \\
40^{\circ} 22^{\prime} \mathrm{N}, 116^{\circ} 20^{\prime} \mathrm{E}\end{array}$ \\
\hline $\begin{array}{l}\text { Paenibacillus } \\
\text { sp. SZ-1b }\end{array}$ & Rods & Moist, milky & $11868.65 \pm 1740.55^{\mathrm{a}}$ & MF967284 & $\begin{array}{l}\text { Maize, farmland in } \\
\text { Changping, Beijing }\end{array}$ \\
\hline $\begin{array}{l}\text { Paenibacillus } \\
\text { sp. BJ-4 }\end{array}$ & Rods & Dry, milky & $1296.94 \pm 439.17^{\mathrm{g}}$ & MF967285 & $\begin{array}{c}40^{\circ} 22^{\prime} \mathrm{N}, 116^{\circ} 20^{\prime} \mathrm{E} \\
\text { Apple, orchard in Shunyi, } \\
\text { Beijing }\end{array}$ \\
\hline $\begin{array}{l}\text { Paenibacillus } \\
\text { sp. BJ-5 }\end{array}$ & Rods & Dry, white & $468.63 \pm 42.20^{\mathrm{hijk}}$ & MF967286 & $\begin{array}{l}40^{\circ} 13^{\prime} \mathrm{N}, 116^{\circ} 65^{\prime} \mathrm{E} \\
\text { Persimmon, mountain in } \\
\text { Shunyi, Beijing }\end{array}$ \\
\hline $\begin{array}{l}\text { Paenibacillus } \\
\text { sp. SZ-8 }\end{array}$ & Rods & Moist, milky & $1131.54 \pm 15.92^{\mathrm{gh}}$ & MF967287 & $\begin{array}{c}40^{\circ} 13^{\prime} \mathrm{N}, 116^{\circ} 65^{\prime} \mathrm{E} \\
\text { Maize, field in Changping, } \\
\text { Beijing }\end{array}$ \\
\hline $\begin{array}{l}\text { Paenibacillus } \\
\text { sp. BJ-7 }\end{array}$ & Rods & Moist, milky & $314.60 \pm 19.18^{\mathrm{jk}}$ & MF967288 & $\begin{array}{l}40^{\circ} 22^{\prime} \mathrm{N}, 116^{\circ} 20^{\prime} \mathrm{E} \\
\text { Wheat, farmland in } \\
\text { Miyun, Beijing }\end{array}$ \\
\hline $\begin{array}{c}\text { Paenibacillus } \\
\text { sp. SZ-10 }\end{array}$ & Short rods & Moist, milky & $371.28 \pm 7.67^{\mathrm{ijk}}$ & MF967289 & $\begin{array}{l}40^{\circ} 37^{\prime} \mathrm{N}, 116^{\circ} 85^{\prime} \mathrm{E} \\
\text { Maize, farmland in } \\
\text { Changping, Beijing } \\
40^{\circ} 22^{\prime} \mathrm{N}, 116^{\circ} 20^{\prime} \mathrm{E}\end{array}$ \\
\hline
\end{tabular}




\begin{tabular}{|c|c|c|c|c|c|}
\hline $\begin{array}{l}\text { Paenibacillus } \\
\text { sp. SZ-11 }\end{array}$ & Rods & Moist, milky & $857.47 \pm 114.89^{\text {ghij }}$ & MF967290 & $\begin{array}{l}\text { Pepper, herbary in } \\
\text { Changping, Beijing }\end{array}$ \\
\hline $\begin{array}{c}\text { Paenibacillus } \\
\text { sp. SZ-13a }\end{array}$ & Rods & Dry, milky & $9731.36 \pm 259.71^{b}$ & MF967291 & $\begin{array}{l}40^{\circ} 22^{\prime} \mathrm{N}, 116^{\circ} 20^{\prime} \mathrm{E} \\
\text { Medicinal plant, farmland } \\
\text { in Changping, Beijing }\end{array}$ \\
\hline $\begin{array}{c}\text { Paenibacillus } \\
\text { sp. SZ-13b }\end{array}$ & Rods & Dry, milky & $3131.89 \pm 100.61^{\mathrm{e}}$ & MF967292 & $\begin{array}{l}40^{\circ} 22^{\prime} \mathrm{N}, 116^{\circ} 20^{\prime} \mathrm{E} \\
\text { Medicinal plant, farmland } \\
\text { in Changping, Beijing }\end{array}$ \\
\hline $\begin{array}{l}\text { Paenibacillus } \\
\text { sp. SZ-15 }\end{array}$ & Rods & Moist, milky & $1316.19 \pm 36.64 \mathrm{~g}$ & MF967293 & $\begin{array}{l}40^{\circ} 22^{\prime} \mathrm{N}, 116^{\circ} 20^{\prime} \mathrm{E} \\
\text { Wheat, farmland in } \\
\text { Changping, Beijing }\end{array}$ \\
\hline $\begin{array}{l}\text { Paenibacillus } \\
\text { sp. SZ-16 }\end{array}$ & Rods & Moist, milky & $444.73 \pm 119.11^{\mathrm{hijk}}$ & MF967294 & $\begin{array}{l}40^{\circ} 22^{\prime} \mathrm{N}, 116^{\circ} 20^{\prime} \mathrm{E} \\
\text { Spinach, herbary in } \\
\text { Changping, Beijing }\end{array}$ \\
\hline $\begin{array}{l}\text { Paenibacillus } \\
\text { sp. BJ-6 }\end{array}$ & Short rods & Dry, milky & $176.7 \pm 29.43^{\mathrm{jk}}$ & MF967295 & $\begin{array}{l}40^{\circ} 22^{\prime} \mathrm{N}, 116^{\circ} 20^{\prime} \mathrm{E} \\
\text { Bamboo, mountain in } \\
\text { Huairou, Beijing }\end{array}$ \\
\hline $\begin{array}{l}\text { Paenibacillus } \\
\text { sp. AH-1 }\end{array}$ & Short rods & Moist, milky & $192.43 \pm 73.08^{\mathrm{jk}}$ & MF967296 & $\begin{array}{c}40^{\circ} 32^{\prime} \mathrm{N}, 116^{\circ} 62^{\prime} \mathrm{E} \\
\text { Grape, orchard in Hefei, } \\
\text { Anhui }\end{array}$ \\
\hline $\begin{array}{l}\text { Paenibacillus } \\
\text { sp. SZ-14 }\end{array}$ & Rods & Moist, milky & $331.95 \pm 22.73^{\mathrm{jk}}$ & MF967297 & $\begin{array}{l}31^{\circ} 86^{\prime} \mathrm{N}, 117^{\circ} 27^{\prime} \mathrm{E} \\
\text { Rice, farmland in } \\
\text { Changping, Beijing }\end{array}$ \\
\hline $\begin{array}{l}\text { Paenibacillus } \\
\text { sp. YN-3 }\end{array}$ & Short rods & Moist, white & $3201.92 \pm 104.96^{\mathrm{e}}$ & MF967298 & $\begin{array}{l}40^{\circ} 22^{\prime} \mathrm{N}, 116^{\circ} 20^{\prime} \mathrm{E} \\
\text { Sugarcane, farmland in } \\
\text { Pu'er, Yunnan }\end{array}$ \\
\hline $\begin{array}{l}\text { Paenibacillus } \\
\text { sp. AH-3 }\end{array}$ & Short rods & Moist, white & $57.23 \pm 14.44^{\mathrm{k}}$ & MF967299 & $\begin{array}{l}23^{\circ} 07^{\prime} \mathrm{N}, 110^{\circ} 03^{\prime} \mathrm{E} \\
\text { Arbor, natural forest in } \\
\text { Wuhu, Anhui }\end{array}$ \\
\hline Paenibacillus & Short rods & Moist, white & $6514.37 \pm 997.12^{c}$ & MF967300 & $\begin{array}{l}31^{\circ} 95^{\prime} \mathrm{N}, 118^{\circ} 73^{\prime} \mathrm{E} \\
\text { Arbor, natural forest in }\end{array}$ \\
\hline
\end{tabular}


sp. AH-4

\begin{tabular}{|c|c|c|c|c|c|}
\hline $\begin{array}{l}\text { Paenibacillus } \\
\text { sn YB-3 }\end{array}$ & Rods & Moist, milky & $733.92 \pm 49.28^{\mathrm{ghijk}}$ & MF967301 & $\begin{array}{c}\text { Fruit, mountain in Yibin, } \\
\text { Sichuan }\end{array}$ \\
\hline $\begin{array}{l}\text { Paenibacillus } \\
\text { sp. WF-6 }\end{array}$ & Rods & Moist, milky & $2081.30 \pm 340.66^{f}$ & MF967302 & $\begin{array}{c}28^{\circ} 77^{\prime} \mathrm{N}, 104^{\circ} 62^{\prime} \mathrm{E} \\
\text { Wheat, field in Weifang, } \\
\text { Shandong }\end{array}$ \\
\hline $\begin{array}{l}\text { Paenibacillus } \\
\text { sp. JS-4 }\end{array}$ & Rods & Moist, milky & $6843.56 \pm 365.69^{c}$ & MF967303 & $\begin{array}{c}36^{\circ} 62^{\prime} \mathrm{N}, 119^{\circ} 10^{\prime} \mathrm{E} \\
\text { Reed, countryside in } \\
\text { Suzhou, Jiangsu }\end{array}$ \\
\hline $\begin{array}{l}\text { Paenibacillus } \\
\text { sp. } \mathrm{HN}-1\end{array}$ & Short rods & Moist, milky & $4476.80 \pm 306.64^{d}$ & MF967304 & $\begin{array}{l}31^{\circ} 32^{\prime} \mathrm{N}, 120^{\circ} 62^{\prime} \mathrm{E} \\
\text { Rice, farmland in } \\
\text { Xiangtan, Hunan }\end{array}$ \\
\hline $\begin{array}{l}\text { Paenibacillus } \\
\text { sp. CD-4a }\end{array}$ & Rods & Moist, milky & $272.67 \pm 14.24^{\mathrm{jk}}$ & MF967305 & $\begin{array}{c}27^{\circ} 52^{\prime} \mathrm{N}, 112^{\circ} 53^{\prime} \mathrm{E} \\
\text { Rape, field in Chengdu, } \\
\text { Sichuan }\end{array}$ \\
\hline $\begin{array}{l}\text { Paenibacillus } \\
\text { sp. CD- } 4 \mathrm{~b}\end{array}$ & Short rods & Moist, milky & $5174.69 \pm 478.7^{d}$ & MF967306 & $\begin{array}{l}30^{\circ} 67^{\prime} \mathrm{N}, 104^{\circ} 07^{\prime} \mathrm{E} \\
\text { Fruit, mountain in } \\
\text { Chengdu, Sichuan }\end{array}$ \\
\hline & & & & & $30^{\circ} 67^{\prime} \mathrm{N}, 104^{\circ} 07^{\prime} \mathrm{E}$ \\
\hline
\end{tabular}

a: The unit of nitrogenase activity is $\mathrm{nmol} \mathrm{C}_{2} \mathrm{H}_{4} \cdot \mathrm{mg}^{-1}$ protein $\cdot \mathrm{h}^{-1}$.

Results are means $\pm \mathrm{SE}$ of 3 independent biological replicates. Different letters are significantly different from each other according to the least significant differences (LSD) test $(P<0.05)$. 


\section{Table 2 (on next page)}

Table 2: Antimicrobial activity of the Paenibacillus strains, which inhibit 6 indicator bacteria. 
Table 2. Antimicrobial activity of the Paenibacillus strains, which inhibit 6 indicator bacteria

\begin{tabular}{|c|c|c|c|c|c|c|}
\hline Strains & R. cer & F. gra & G. zeae & F. sol & C. gos & A. lon \\
\hline Paenibacillus sp. BJ-2 & ++ & ++ & ++ & - & +++ & + \\
\hline Paenibacillus sp. SZ-1a & ++ & ++ & ++ & - & ++ & ++ \\
\hline Paenibacillus sp. SZ-1b & +++ & +++ & ++ & - & ++ & +++ \\
\hline Paenibacillus sp. BJ-4 & ++ & +++ & ++ & - & ++ & +++ \\
\hline Paenibacillus sp. BJ-5 & - & +++ & + & - & ++ & ++ \\
\hline Paenibacillus sp. SZ-8 & ++ & +++ & ++ & - & +++ & ++ \\
\hline Paenibacillus sp. BJ-7 & ++ & +++ & +++ & - & ++ & + \\
\hline Paenibacillus sp. SZ-10 & ++ & +++ & +++ & - & ++ & ++ \\
\hline Paenibacillus sp. SZ-11 & ++ & ++ & ++ & - & ++ & ++ \\
\hline Paenibacillus sp. SZ-13a & +++ & ++ & ++ & - & ++ & ++ \\
\hline Paenibacillus sp. SZ-13b & ++ & ++ & ++ & + & ++ & ++ \\
\hline Paenibacillus sp. SZ-15 & +++ & ++ & +++ & - & +++ & ++ \\
\hline Paenibacillus sp. SZ-16 & ++ & ++ & ++ & - & ++ & ++ \\
\hline Paenibacillus sp. BJ-6 & ++ & ++ & - & + & ++ & - \\
\hline Paenibacillus sp. AH-1 & +++ & +++ & +++ & - & ++ & ++ \\
\hline Paenibacillus sp. SZ-14 & ++ & +++ & ++ & - & +++ & ++ \\
\hline Paenibacillus sp. YN-3 & ++ & ++ & ++ & - & ++ & ++ \\
\hline Paenibacillus sp. AH-3 & - & - & - & - & - & - \\
\hline Paenibacillus sp. AH-4 & + & - & - & - & - & - \\
\hline Paenibacillus sp. YB-3 & ++ & +++ & ++ & - & ++ & +++ \\
\hline Paenibacillus sp. WF-6 & ++ & ++ & ++ & - & ++ & ++ \\
\hline Paenibacillus sp. JS-4 & ++ & +++ & ++ & - & +++ & +++ \\
\hline Paenibacillus sp. HN-1 & - & - & - & - & - & - \\
\hline Paenibacillus sp. CD-4a & - & - & - & - & - & - \\
\hline Paenibacillus sp. CD-4b & - & - & - & - & - & - \\
\hline
\end{tabular}

